Report of Investigations 2011-3A

\title{
GEOLOGIC MAP OF THE KAVIK RIVER AREA, NORTHEASTERN BROOKS RANGE, ALASKA
}

by

M.A. Wartes, W.K. Wallace, A.M. Loveland, R.J. Gillis, P.L. Decker, R.R. Reifenstuhl, P.R. Delaney, D.L. LePain, and E.C. Carson

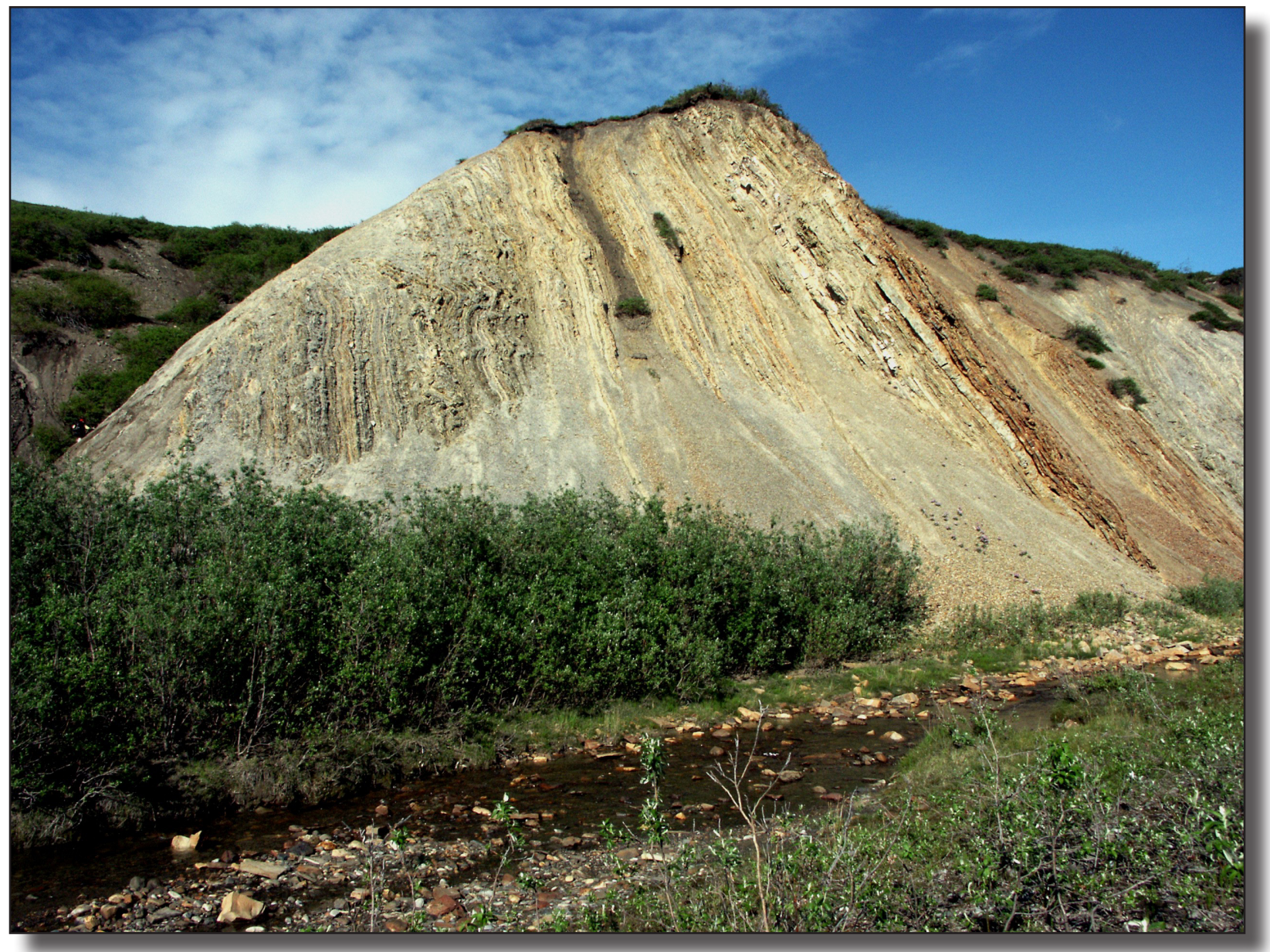

Exposure of the Hue Shale along Juniper Creek. The unit is interpreted as a condensed Brookian section that accumulated in the distal, underfilled portion of the northeastern Colville foreland basin. The Upper Cretaceous portion of the unit shown here includes distinctive bright-weathering silicified tuff, creamy bentonite, and organic-rich fissile shale. Note geologist at far left for scale.

\section{Published by}

STATE OF ALASKA

DEPARTMENT OF NATURAL RESOURCES

DIVISION OF GEOLOGICAL \& GEOPHYSICAL SURVEYS 



\title{
Report of Investigations 2011-3A
}

\section{GEOLOGIC MAP OF THE KAVIK RIVER AREA, NORTHEASTERN BROOKS RANGE, ALASKA}

\author{
by \\ M.A. Wartes, W.K. Wallace, A.M. Loveland, R.J. Gillis, P.L. Decker, \\ R.R. Reifenstuhl, P.R. Delaney, D.L. LePain, and E.C. Carson
}

2011

This DGGS Report of Investigations is a final report of scientific research. It has received technical review and may be cited as an agency publication. 


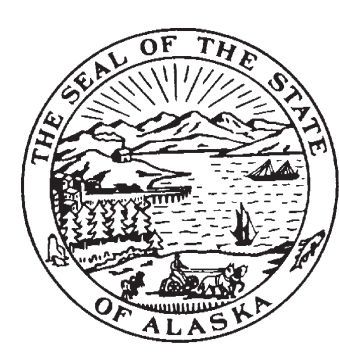

STATE OF ALASKA

Sean Parnell, Governor

DEPARTMENT OF NATURAL RESOURCES

Daniel S. Sullivan Commissioner

\section{DIVISION OF GEOLOGICAL \& GEOPHYSICAL SURVEYS Robert F. Swenson, State Geologist and Director}

Publications produced by the Division of Geological \& Geophysical Surveys (DGGS) are available for free download from the DGGS website (www.dggs.alaska.gov). Publications on hard-copy or digital media can be examined or purchased in the Fairbanks office:

\section{Alaska Division of Geological \& Geophysical Surveys \\ 3354 College Rd., Fairbanks, Alaska 99709-3707 \\ Phone: (907) 451-5020 Fax (907) 451-5050 \\ dggspubs@alaska.gov \\ www.dggs.alaska.gov}

\begin{abstract}
Alaska State Library
State Office Building, 8th Floor

333 Willoughby Avenue

Juneau, Alaska 99811-0571

Elmer E. Rasmuson Library

University of Alaska Fairbanks

Fairbanks, Alaska 99775-1005
\end{abstract}

\author{
Alaska Resource Library \& Information \\ Services (ARLIS) \\ 3150 C Street, Suite 100 \\ Anchorage, Alaska 99503 \\ University of Alaska Anchorage Library \\ 3211 Providence Drive \\ Anchorage, Alaska 99508
}

This publication released by the Division of Geological \& Geophysical Surveys was produced and printed in Fairbanks, Alaska, at a cost of $\$ 15$ per copy. Publication is authorized by Alaska Statute 41, which charges the division "to determine the potential of Alaskan land for production of metals, minerals, fuels, and geothermal resources; the location and supplies of groundwater and construction materials; the potential geologic hazards to buildings, roads, bridges, and other installations and structures; and shall conduct such other surveys and investigations as will advance knowledge of the geology of Alaska." 


\section{CONTENTS}

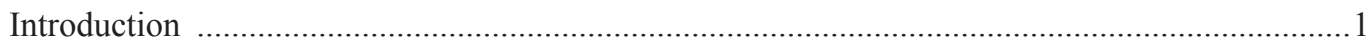

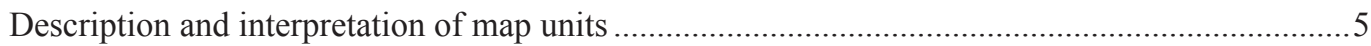

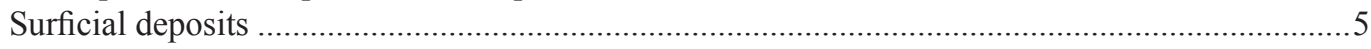

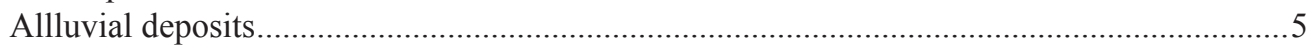

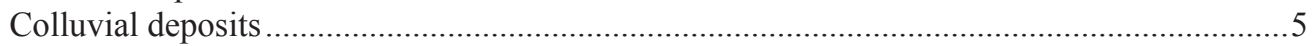

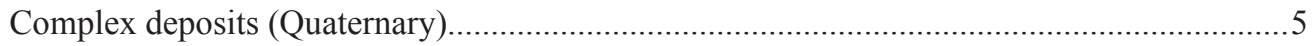

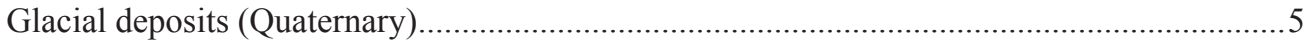

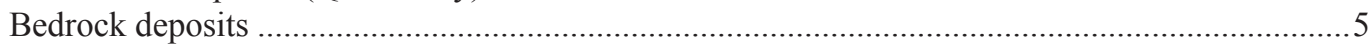

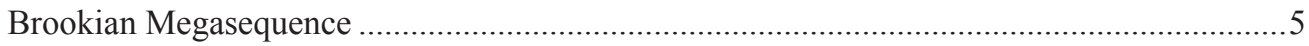

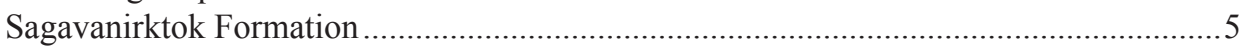

Lower Sagavanirktok Formation, upper part (lower Paleogene [Paleocene]) .............5

Lower Sagavanirktok Formation, middle part (lower Paleogene [Paleocene]) ..........6

Lower Sagavanirktok Formation, lower part (lower Paleogene [Paleocene]) ............6

Canning Formation (Upper Cretaceous to Lower Paleogene [Campanian-Paleocene])...6

Hue Shale unit (Middle to Upper Cretaceous [Aptian-Campanian]) …………………......

Juniper sandstone (Cretaceous) ...................................................................................

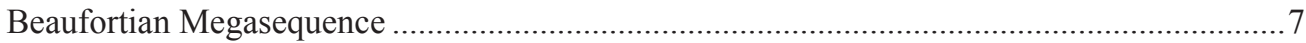

Pebble Shale unit (Lower Cretaceous [Barremian]) ………..............................................

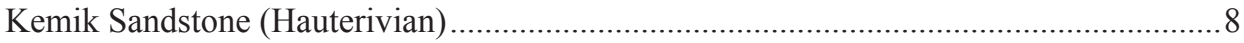



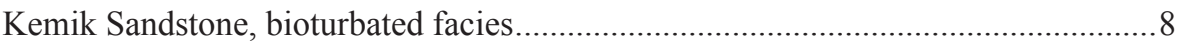

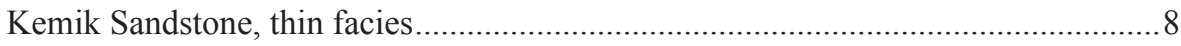

Kingak Formation (Lower Jurassic-Lower Cretaceous [Valanginian])............................ 8

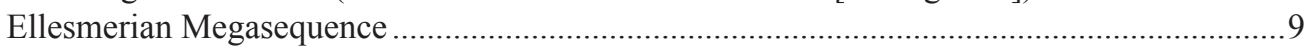

Shublik Formation (Middle to Upper Triassic) ……………………………….................

Sadlerochit Group (Permian to Middle Triassic) …………............................................

Ivishak Formation (Lower to Middle Triassic) ..................................................................

Ivishak Formation, Undifferentiated (Lower to Middle Triassic).............................10

Ivishak Formation, Ledge Sandstone Member (Lower to Middle Triassic) .............10

Ivishak Formation, Kavik Shale Member (Lower Triassic) ......................................10

Echooka Formation (Permian) .................................................................................. 10

Lisburne Group (Mississippian to lower Pennsylvanian) ..............................................10

Lisburne Group, middle and upper parts ............................................................ 10

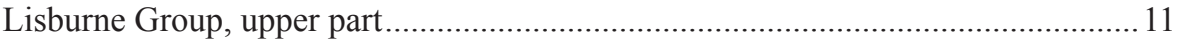

Lisburne Group, middle part................................................................................. 11

Lisburne Group, lower part.................................................................................... 11

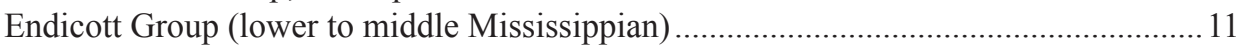



Kekiktuk Conglomerate (lower to middle Mississippian) …………………….................. 11

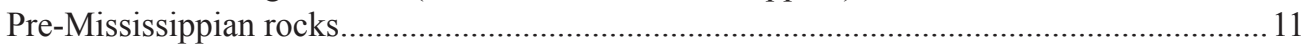

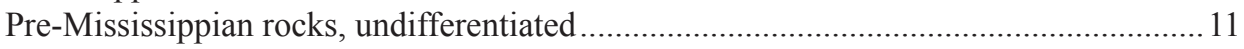

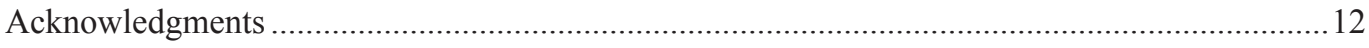

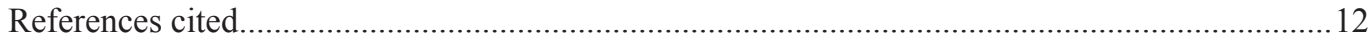

\section{FIGURES}

Figure 1. Regional map depicting major geographic and geologic features and location of

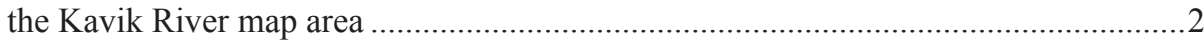

2. Map showing locations of $\sim 700$ bedrock mapping stations visited during the

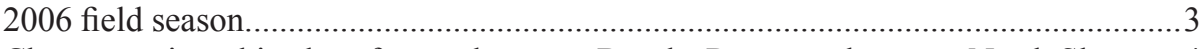

3. Chronostratigraphic chart for northeastern Brooks Range and eastern North Slope.....4 



\title{
GEOLOGIC MAP OF THE KAVIK RIVER AREA, NORTHEASTERN BROOKS RANGE, ALASKA
}

\author{
by \\ M.A. Wartes ${ }^{1}$, W.K. Wallace ${ }^{2}$, A.M. Loveland ${ }^{1}$, R.J. Gillis ${ }^{1}$, P.L. Decker ${ }^{3}$, \\ R.R. Reifenstuhl' ${ }^{1}$, P.R. Delaney ${ }^{1}$, D.L. LePain ${ }^{1}$, and E.C. Carson ${ }^{4}$
}

\section{INTRODUCTION}

The first geologic map covering the Kavik River area of the eastern North Slope and Brooks Range was published at a scale of 1:125,000 by Keller and others (1961), building on the pioneering geologic expeditions in the Canning River area by Leffingwell (1919). The U.S. Geological Survey subsequently released a preliminary 1:250,000-scale map of the Mt. Michelson Quadrangle (Reiser and others, 1971), which was later modified slightly and incorporated in regional compilation efforts by Bader and Bird (1986) and Bird (1999). The only published 1:63,360-scale geologic mapping in the study area covers the western bank of the Canning River and was included in the Sadlerochit and Shublik Mountains map of Robinson and others (1989).

This Kavik River geologic map (sheet 1) is the final product of 24 days of helicopter-supported field work during 2006 and two brief reconnaissance field seasons in 2004 and 2005. All fieldwork was conducted from a base camp at the Kavik River airstrip in the northwestern corner of the map area (sheet 1). The 1:63,360-scale map covers more than $1,550 \mathrm{~km}^{2}\left(600 \mathrm{mi}^{2}\right)$, including the complete Mt. Michelson B-5 and C-5 quadrangles and the western portion of the B-4 and C-4 quadrangles (fig. 1). During the course of mapping, data were collected from approximately 700 bedrock field stations (fig. 2).

In addition to surface geologic constraints, available subsurface data (seismic and well logs) were integrated to better constrain stratigraphic and structural relationships. Geophysical logs were consulted for the six industry wells in the northern quarter of the map area (Nelson and others, 1999; see fig. 1 and sheet 1, this report for locations). Six two-dimensional (2-D) seismic lines were available, including three south-north lines, or composite lines, and three east-west tie-lines.
These data were acquired in an ARCO group shoot in 1980 and 1981 and were later released to the public by the U.S. Geological Survey ${ }^{5}$. The south-north lines are particularly useful in resolving the structural style, and we chose to construct cross sections along these lines (sheet 1 shows location). Data quality is very poor in the southern portions of the seismic lines and none of the lines continue into the higher relief areas in the southern part of the map. Nevertheless, the cross sections continue to the southern edge of the map and are constrained solely by surface geology. These cross sections and an accompanying discussion can be found in the companion publication by Wallace (in review).

The Kavik River region is one of the few areas that permit examination of all three depositional megasequences $^{6}$ of northern Alaska in close association. The temporal and spatial relationships of these megasequences (Ellesmerian, Beaufortian, and Brookian) are illustrated on the chronostratigraphic chart (fig. 3). An additional incentive to map the geology of the Kavik River area stems from the economic relevance of many of the stratigraphic units exposed. Several occurrences of oil-stained sandstone have been noted in outcrop (Burruss, 1999), and the undeveloped Kavik field that lies in the north-central part of the map is estimated to contain 165 billion standard cubic feet of natural gas (Verma and others, 2005). In concert with geologic mapping, stratigraphic units significant for oil and gas exploration were examined in detail, including acquisition of a number of measured sections. Local analysis of the sedimentology and stratigraphy focused particularly on the more prospective Beaufortian and Brookian units. This focus can be seen in the level of detail provided in the unit descriptions below.

\footnotetext{
${ }^{1}$ Alaska Division of Geological \& Geophysical Surveys, 3354 College Road, Fairbanks, AK 99709-3707; marwan.wartes@alaska.gov; 907-451-5056

${ }^{2}$ Department of Geology \& Geophysics, University of Alaska, PO Box 757320, Fairbanks, AK 99775-7320

${ }^{3}$ Alaska Division of Oil \& Gas, 550 W 7th Ave., Ste 800, Anchorage, AK 99501-3560

${ }^{4}$ Wisconsin Geological \& Natural History Survey, 3817 Mineral Point Rd., Madison, WI 53705-5100

${ }^{5}$ Seismic data are available for download at the U.S. Geological Survey National Archive of Marine Seismic Surveys (http://walrus.wr.usgs. gov/NAMSS/search_and_download_data.html). Data for the survey that covers the Kavik River area are labeled "WesternGeco, North Slope (W-40-80-AK)."

${ }^{6}$ The term "megasequence" was applied to Arctic Alaska by Hubbard and others (1987) as a modification of the tectonic sequence scheme first proposed by Lerand (1973). The term megasequence recognizes deposition under specific phases of basin development, thus capturing major stages in the tectonic evolution of the region. Many authors substitute the term "sequence", a practice that is avoided here due to the potential for confusion with the now well-defined nomenclature associated with sequence stratigraphy (Catuneanu and others, 2009).
} 




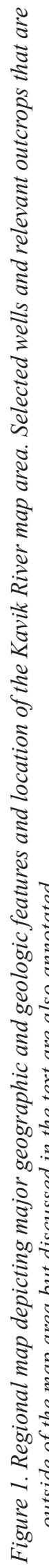




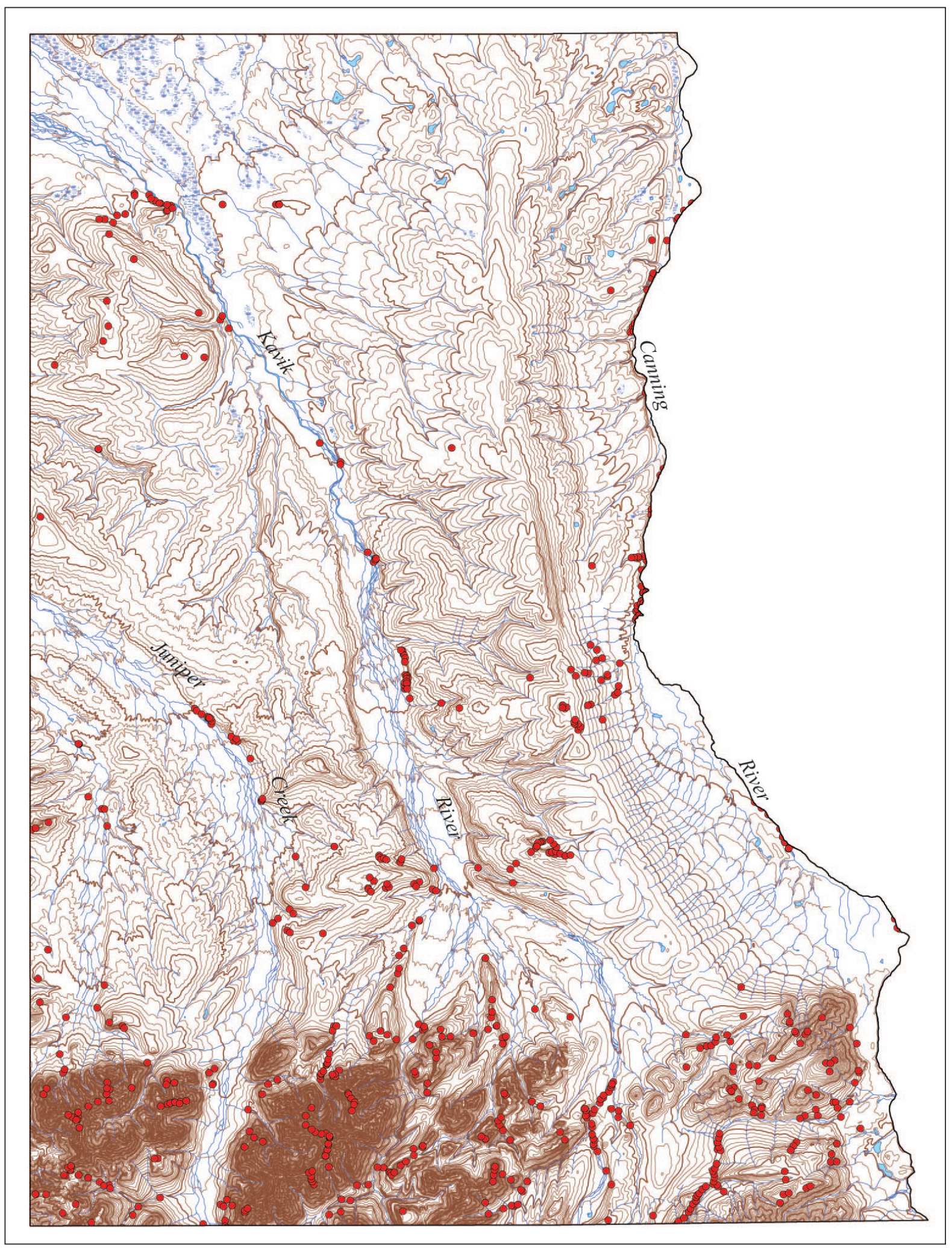

Figure 2. Map showing locations of $\sim 700$ bedrock mapping stations visited during the 2006 field season. 


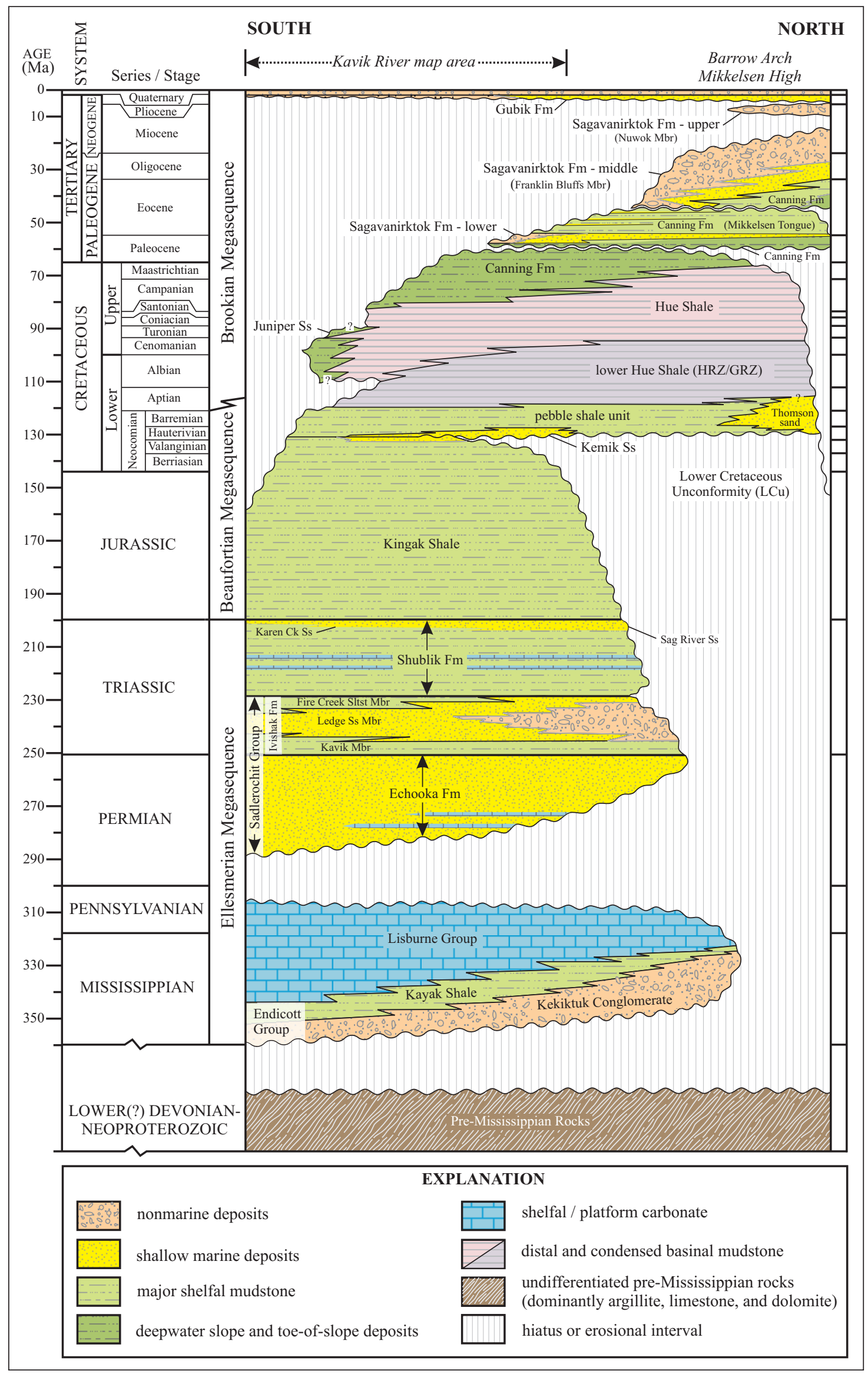

Figure 3. Chronostratigraphic chart for northeastern Brooks Range and eastern North Slope, modified and revised from Decker and others (in press), Mull and others (2003), Garrity and others (2005), and Detterman and others (1975). 


\section{DESCRIPTION AND INTERPRETATION OF MAP UNITS \\ SURFICIAL DEPOSITS}

(Simplified from Carson [2009]—See primary reference for detailed surficial geologic mapping and more comprehensive unit divisions and descriptions)

Qa ALLUVIAL DEPOSITS (Quaternary)—Undifferentiated alluvial deposits, including modern streams, abandoned channels, alluvial fans, and alluvial terraces. Dominantly consists of moderately to well sorted, rounded to sub-rounded, locally stratified cobble and pebble gravel with lesser sand and minor silt.

Qc COLLUVIAL DEPOSITS (Quaternary) - Undifferentiated colluvial deposits, including coarse- to fine-grained colluvium and landslide deposits consisting of poorly sorted, sub-angular to angular, boulder-rich gravel with variable amounts of sand and silt matrix that typically form aprons and fans near the base of bedrock slopes. Thaw lake deposits are also included in this unit and consist of poorly to moderately stratified silt and organic silt that are often modified by thawing of permafrost and local streamflow.

Qs COMPLEX DEPOSITS (Quaternary)-Undifferentiated silt deposits ranging from irregular blankets of massive, unconsolidated aeolian silt to moderately stratified silt and organics. Deposits are variably influenced by melting of ice-rich zones and modified by gravitational slope processes.

Qg GLACIAL DEPOSITS (Quaternary) - Undifferentiated glacial drift, outwash, and kame terraces ascribed to the Itkillik (I and II), Sagavanirktok River, and Anaktuvuk River glaciations. Drift deposits are typically associated with remnant moraine topography composed of matrix-supported boulder and cobble gravel that is poorly sorted, non-stratified, and often includes striated and faceted clasts. Outwash and kame deposits are dominantly well sorted, clast-supported, massive to weakly stratified cobble and pebble gravel.

\section{BEDROCK DEPOSITS}

\section{BROOKIAN MEGASEQUENCE}

In northern Alaska, the term Brookian megasequence refers to all rocks derived from the Brooks Range orogen. These mineralogically immature clastic deposits generally prograded longitudinally to the northeast, eventually filling the Colville foreland basin by the Paleogene (Bird and Molenaar, 1992). In foothills of the northeastern Brooks Range, the Brookian sequence is composed of four map units: (1) the lower Paleogene to lower Neogene Sagavanirktok Formation, (2) the Upper Cretaceous to Paleogene Canning Formation, (3) the middle to Upper Cretaceous Hue Shale, and (4) the middle(?) to Upper Cretaceous Juniper sandstone (informal). Most Brookian units are time-transgressive and interfinger at a regional scale. The formation nomenclature is based in part on lithostratigraphic criteria, resulting in local occurrences of the same unit both above and below another unit. For example, see the Upper Cretaceous to Neogene intertonguing of the Sagavanirktok and Canning Formations illustrated in figure 3 .

SAGAVANIRKTOK FORMATION (lower Paleogene to lower Neogene [Paleocene-Miocene])—Weakly consolidated sandstone, pebbly sandstone, carbonaceous mudstone, siltstone, conglomerate and coal, interpreted as deltaic, shallow marine and nonmarine deposits that intertongue with finer-grained facies ascribed to the Canning Formation (Molenaar and others, 1987). Unit was subdivided into four members by Mull and others (2003); due to lateral facies changes, a slightly modified nomenclature is adopted here, employing the terms lower, middle and upper (fig. 3). Only the lower Sagavanirktok Formation is preserved in the map area, where it is further subdivided into three informal units that correspond to sandstone-rich tongues recognized in nearby well logs (Molenaar and others, 1986). The lower Sagavanirktok is partly equivalent to the Jago River Formation exposed east of the Sadlerochit Mountains (Buckingham, 1987; fig. 1), and the Sagwon and White Hills members exposed to the west, in the vicinity of the Dalton Highway (Mull and others, 2003; fig. 1).

Tslu LOWER SAGAVANIRKTOK FORMATION, UPPER PART (lower Paleogene [Paleocene])— Limited to a single rubble exposure in the northwestern part of the map area consisting of poorly 
consolidated, probably fluvial conglomerate. Clasts average $5 \mathrm{~mm}$ to $2 \mathrm{~cm}$ in diameter and range up to $12 \mathrm{~cm}$ cobbles; dominant clast lithologies include light gray fine-grained quartzite, white vein quartz, and lesser varieties of black, gray, green, and red chert and siliceous mudstone. Assignment is based on available seismic data and projections from nearby wells; equivalent to the Staines Tongue of Molenaar and others (1987). Unit is not preserved in its entirety in the subsurface of the map area, but southward thickening observed in well correlations suggests it was originally slightly thicker than the $268 \mathrm{~m}$ calculated for the type section in the West Staines-2 well (Molenaar and others, 1987).

TsIm LOWER SAGAVANIRKTOK FORMATION, MIDDLE PART (lower Paleogene [Paleocene]) - Light-gray- to tan-weathering, dominantly very-fine- to fine-grained, moderately sorted, salt-and-pepper sandstone. Tabular to wavy non-parallel beds range from 2 to $35 \mathrm{~cm}$ thick and include burrow-mottled massive to plane-parallel laminated facies and locally well developed low-angle and hummocky cross-stratification. A variable, but locally strong hydrocarbon odor is noted in many beds. Medium-gray-weathering, chippy siltstone commonly preserves load structures at the contact with overlying sandstone beds. Granule and pebble stringers are present, expanding locally into irregular conglomerate beds up to $35 \mathrm{~cm}$ thick. Carbonized wood fragments are abundant in some beds. Interval is interpreted as lower shoreface to delta front, possibly including small distributary channel deposits. Only occurrence is in the northeast corner of the map area along the west bank of the Canning River, where $120 \mathrm{~m}$ of section is exposed in the footwall of the Kavik fault. Assignment is based principally on projections from nearby Canning River Unit B-1 well and available seismic data; equivalent to an unnamed tongue illustrated in well log cross sections by Molenaar and others (1986) and Bird (1999); total thickness of 846 $\mathrm{m}$ is calculated for this tongue in the Beli 1 well (north-central part of map; Nelson and others, 1999).

Tsll LOWER SAGAVANIRKTOK FORMATION, LOWER PART (lower Paleogene [Paleocene])Light-gray-weathering, fine- to coarse-grained, friable, salt-and-pepper sandstone; commonly trough cross-stratified and locally includes abundant granule- and pebble-rich horizons composed of white vein quartz and dark gray chert clasts. Plant fossil impressions are locally abundant and a prominent hydrocarbon odor is detected in some outcrops, particularly those nearest the Kavik fault. Fine-grained intervals are recessive and generally covered, although limited exposures along the Kavik River include carbonaceous mudstone, coal, siltstone, and thin bentonite seams. Unit is interpreted as dominantly nonmarine fluvial and associated overbank facies. Discontinuously exposed in uplands of the western part of map area between Juniper Creek and the Kavik fault; forms moderately resistant mesa tops covered by large sandstone blocks. Unit is illustrated in well $\log$ cross sections by Molenaar and others (1986) and Bird (1999); referred to in Nelson and others (1999) as the lower, unnamed tongue of the Sagavanirktok Formation, where a thickness of $289 \mathrm{~m}$ was calculated for the Beli 1 well (north-central part of map) and $385 \mathrm{~m}$ for the Canning B-1 well (northeast part of map). Surface exposures were previously referred to as Prince Creek Formation in Reifenstuhl and others (2000) and Mull and others (2003).

TKC CANNING FORMATION (Upper Cretaceous to lower Paleogene [Campanian-Paleocene])Medium to dark gray nonbioturbated shale and slightly micaceous siltstone punctuated by thin, tabular interbeds of light to medium gray lithic, very-fine- to fine-grained sandstone. Sandstone commonly rich in carbonaceous detritus and coalified woody debris; bedding rarely amalgamates into thick bed-sets and is typically rhythmic and locally exhibits partial Bouma sequences (Bouma, 1962), sole marks, and mud rip-up clasts suggesting turbidite deposition; interpreted as marine slope and basin floor facies (Molenaar and others, 1987; Houseknecht and Schenk, 1999). Gray to yellow thin bentonite seams are common in the lower part of the unit; the base of the formation is picked at the lowest occurrence of sandstone beds. A significant intra-Canning Paleocene submarine unconformity is interpreted from regional subsurface data (Houseknecht and Schenk, 1999; Wartes and others, 2011; fig. 3), although it was not observed in outcrop. Unit is discontinuously exposed along most river bluffs in the central and north-central parts of map area; best exposures along the Canning River, Kavik River, and Juniper Creek; the latter outcrop 
includes broken formation (in the sense of Hsu, 1968). Wells in the northern part of the map area suggest a thickness of 1,100-1,200 m, as measured from top of the Hue Shale to the base of the first tongue of the lower Sagavanirktok; although not exposed in the map area, an additional 298 $\mathrm{m}$ of fine-grained shelfal facies ascribed to the Canning Formation intertongues with the lower Sagavanirktok Formation; the Eocene Mikkelson tongue of the Canning Formation separates the lower and middle Sagavanirktok Formation and is approximately $930 \mathrm{~m}$ thick in the Alaska State J-1 well about $15 \mathrm{~km}$ north of the map area (Nelson and others, 1999; Bird, 1999).

Kh HUE SHALE UNIT (middle to Upper Cretaceous [Aptian-Campanian])—Dark gray organicrich paper shale, yellow-green bentonite, and resistant, hard, orange-yellow silicified tuff. Unit weathers a distinctive buff white to tan and yellow color due to abundant air-fall volcanic material; interpreted as distal, condensed, basin-floor facies. Exposures are limited to a complexly folded and faulted zone in the central part of the map area along the Kavik River and Juniper Creek. In well logs, the lower part of this unit includes a distinctive zone locally referred to as the "gamma ray zone" (GRZ) (Tailleur and others, 1978) or the "highly radioactive zone" (HRZ) (Carmen and Hardwick, 1983). The local presence of the Juniper sandstone immediately above the Pebble Shale suggests the lower part of the Hue Shale is locally not present in the southern part of the map area, presumably due to either clastic dilution or submarine erosion (fig. 3). Unit thickness reported for nearby wells varies from $200 \mathrm{~m}$ in the Beli 1 well to $361 \mathrm{~m}$ for the Kavik 1 well (Nelson and others, 1999) - the higher values may reflect structural thickening of this incompetent unit; Molenaar and others (1987) measured $222 \mathrm{~m}$ for the type section in the northern Shublik Mountains, approximately $20 \mathrm{~km}$ east of the map area; Macquaker and others (1999) referenced work by Bergman and others (1995) along the Canning River where a thickness of approximately $218 \mathrm{~m}$ was calculated.

Kjs JUNIPER SANDSTONE (Cretaceous) - Poorly exposed very-fine- to fine-grained lithic sandstone in a folded belt in the south-central part of the map area between Juniper Creek and the large moraine bounding the western side of the Canning River. Most of unit is covered, although base is exposed above the Pebble Shale unit, approximately 3 to $5 \mathrm{~km}$ east of the Kavik River, where it consists of dark gray rippled sandstone locally exhibiting a purplish-maroon-weathering sheen and lesser fissile siltstone. Between the Kavik River and Juniper Creek, higher stratigraphic levels are exposed in resistant benches up to $10 \mathrm{~m}$ thick and are composed of tan to light gray fine-grained sandstone exhibiting blocky to flagstone weathering; bedding and stratification range from heavily fractured massive intervals to subtly ripple cross-laminated and planar to trough cross-stratified zones. Mudstone is not observed interstratified with the sandstone benches, but is inferred to underlie intervening recessive swales, possibly including tongues of the Hue Shale. Map unit is not recognized in outcrops of coeval strata in the central part of the map, or in wells to the north, suggesting abrupt northward fining and thinning. Depositional environment is poorly constrained but inferred to be entirely marine, probably in a slope or basin floor setting. The name 'Juniper sandstone' is informally applied here for the first time; previous reconnaissance mapping referred to these rocks as Canning Formation (Bader and Bird, 1986) and 'Albian turbidites' (Mull, 1987). This interval is likely correlative in part with other enigmatic sections preserved on strike at a similar latitude, and noted on figure 1, including: Gilead sandstone (Reifenstuhl, 1991; Decker and others, 2008), Arctic Creek unit (Molenaar and others, 1987; Mull and Decker, 1993), and Bathtub Graywacke (Detterman and others, 1975; Camber and Mull, 1986). Thickness is unknown, but suspected to be several hundred meters.

\section{BEAUFORTIAN MEGASEQUENCE}

The Beaufortian megasequence is a Jurassic to Lower Cretaceous rift-related succession associated with the opening of the Canada Basin (Hubbard and others, 1987). The uplift of rift shoulders amplified the composite Barrow Arch structural high, across which significant erosion occurred, culminating in the regional Lower Cretaceous unconformity (LCu) (Bird, 1987; fig. 3). In the Kavik River area, the Jurassic to Early Cretaceous Kingak Shale underlies the $\mathrm{LCu}$ and its correlative conformity. A Lower Cretaceous transgressive assemblage overlies the $\mathrm{LCu}$ and includes the Early Cretaceous Kemik Sandstone overlain by the Pebble Shale unit. 
Kps PEBBLE SHALE UNIT (Lower Cretaceous [Barremian])—Medium to dark gray, soft, subfissile claystone and siltstone that weathers into small, equant chips. Ironstone concretions are locally abundant. Unit includes rare outsized floating grains (typically sand, granule, and small pebbles); dark gray to black chert is the most common grain type, although quartzite, argillite, vein quartz, limestone, and schist have been reported (Mull, 1987). Typically poorly exposed, but found locally in association with the resistant Kemik Sandstone along the Canning River and Fin Creek. Unit is interpreted as a trangressive shelfal mudstone, influenced by seasonal ice-related processes (Macquaker and Keller, 2005; van der Kolk, 2010). Reported subsurface thickness ranges from $17 \mathrm{~m}$ at the Beli 1 well to $72 \mathrm{~m}$ in the Kavik 2 well (Nelson and others, 1999); excavation of a complete section along the Canning River yielded a measured thickness of 28-32 m (Macquaker and others, 1999; van der Kolk, 2010). Equivalent to the subsurface Kalubik Formation of Carmen and Hardwick (1983).

KEMIK SANDSTONE (Hauterivian) - Resistant, tan to light brown, quartzose sandstone exposed above the $\mathrm{LCu}$ and its correlative conformity to the south (Mull, 1987; Molenaar and others, 1987); occupies the same stratigraphic position as the upper Kuparuk Formation (Schenk and Houseknecht, 2008; Carmen and Hardwick, 1983). Age well-constrained by the ammonites Simberskites sp. (Detterman and others, 1975) and Shasticrioceras sp. (W.P. Elder, written commun.). Unit is subdivided here into three facies belts (massive, bioturbated, and thin), modified from Reifenstuhl and others (2000). Nature of the relationship between mapped belts is unclear, and some outcrops exhibit characteristics of both the massive and bioturbated facies. The observed range of facies and thicknesses may reflect paleotopography (such as incised valleys) and/or variable accommodation generated during small-scale Hauterivian(?) normal faulting.

Kkm KEMIK SANDSTONE, MASSIVE FACIES—Dominantly massive to trough and low-angle cross-bedded, fine- to very-fine-grained, glauconite bearing, quartz-rich sandstone; weathers tan to light gray, except where surface is colonized by black lichen. Chert pebble lags are uncommon and best developed at the sharp contact with the overlying Pebble Shale unit. Rare thin mudstone intervals are gray to reddish brown and rippled; base of section typically includes a thin, enigmatic, orange-weathering, hard siltstone with scattered floating, medium to very coarse, translucent quartz sand grains. Locally abundant ichofauna dominated by $25-50-\mathrm{cm}-$ long Skolithos burrows and lesser examples of Planolites, Ophiomorpha, Rosellia, Cylindrichnus, and Chondrites; pelecypods and ammonites also are observed. Forms rubble-covered, resistant ridges and mesas, best expressed along cliff exposures on the west bank of the Canning River. Trace fossils, body fossils, and sedimentology support a shallow marine, shoreface interpretation (see also Knock, 1986; Reifenstuhl, 1995). Thickness in outcrop varies from 20 to $30 \mathrm{~m}$.

Kkb KEMIK SANDSTONE, BIOTURBATED FACIES-Dark brown to gray, very-fine-grained sandstone and very thin mudstone partings; unit characterized by omnipresent bioturbation that locally yields a mottled fabric. Recognizable individual trace fossils include Terebellina, Paleophycos, Gyrochorte, Conichnus, and Cosmorhaphe - the latter being especially common. Subtle parasequences $2-7 \mathrm{~m}$ thick can be recognized based on variations in bioturbation intensity and thickening- and coarsening-upward trends. Distinctive thin bimodal siltstone with floating quartz grains is also observed at the base of this facies association. Best exposure is found near the western edge of the map area at VABM Bury. Depositional environment is interpreted as lower energy than the Kkm, likely in a lower shoreface to outer shelf setting. A measured section at VABM Bury yielded an approximate thickness of $75 \mathrm{~m}$.

Kkt KEMIK SANDSTONE, THIN FACIES - Beige- to tan-weathering, massive, very-fine-grained quartz sandstone; facies similar to Kkm except for the presence of mud rip-ups and the much thinner total section $(0-3 \mathrm{~m})$. Unit is marked by blocky rubble that can be traced along a linear tundra-mantled rib in the south-central part of the map area, north of the Juniper sandstone outcrop belt; best exposure is east of the Kavik River where a possibly conformable relationship with upper Kingak and lower Pebble Shale unit can be observed (Mull, 1987). Inferred to be outer shelf to lower shoreface storm deposits based on southerly (basinward) position, irregular preservation, and common mud rip-ups. 
KJk KINGAK FORMATION (Lower Jurassic-Lower Cretaceous [Valanginian])—Dark gray to black soft clay shale, locally fissile and containing abundant bedding-parallel, reddish-orangeto brown-weathering sideritic(?) concretions, and lesser thin very-fine-grained sandstone beds. Typically recessive and only exposed in small discontinuous stream cutbanks, most notably in the southern part of the map area, directly north of the mountain front; also exposed in structural low in southeast corner of map. Locally well exposed beneath the LCu and Kemik Sandstone along the Canning River; near the Kkt unit, uppermost Kingak displays a resistant subcrop weathering pattern reflecting an upward increase in sandstone. Interpreted as quiet-water shelf deposits, possibly grading upward into prodelta turbidites near the top. May be as thick as $350 \mathrm{~m}$ (Molenaar, 1983), although inferred structural thickening of this mechanically weak section limits accurate estimates; wells in the northern part of the map area suggest an average thickness closer to 200 $\mathrm{m}$ (Nelson and others, 1999), although this is a minimum due to the northward increase of erosion along the $\mathrm{LCu}$ (Bird, 1999). The Lower Cretaceous part of the formation is equivalent to the Miluveach Formation of subsurface usage (Carmen and Hardwick, 1983).

\section{ELLESMERIAN MEGASEQUENCE}

The Ellesmerian megasequence consists of Mississippian to Triassic strata derived from a northern source area (Hubbard and others, 1987). Regional northward onlapping patterns suggest the megasequence records the development of a south-facing passive margin (Moore and others, 1994). In the map area, exposures of this succession are limited to alpine topography in the southernmost part of the map; more northerly exposures are found to the east in the Sadlerochit and Shublik mountains (Robinson and others, 1989). The base of the megasequence is marked by a major pre-middle Devonian unconformity, which in the map area is overlain by the Mississippian Endicott Group, a nonmarine to transgressive marine succession. This is followed by the broad carbonate platform deposits of the Mississippian to Pennsylvanian Lisburne Group. Following another major unconformity (Lower Permian), the megasequnce is re-established as a siliciclastic-dominated margin during deposition of the Permian-Triassic Sadlerochit Group, Triassic Shublik Formation, and the Sag River Sandstone. The Sag River Sandstone is not recognized in outcrop, but is generally regarded as equivalent to the Karen Creek Sandstone (Detterman and others, 1975), which occupies the same stratigraphic position (fig. 3).

ks SHUBLIK FORMATION (Middle to Upper Triassic) —-Dark gray to black organic-rich mudstone and sooty paper shale, calcareous sandstone and siltstone, and distinctive nodular, phosphate-rich beds. Thin-bedded micritic limestone yields a fetid odor on freshly broken surfaces and locally contains abundant fossil hash including Monotis sp. and Halobia sp. pelecypods. Generally recessive and exposures limited to a few stream cutbanks along the mountain front (especially Cobble Creek and Kavik River) and locally in structural lows in the southeastern part of the map area. Unit includes rocks assigned to the Karen Creek Sandstone, which regionally overlies the Shublik Formation; in the map area, this interval is partially exposed along the Kavik River and composed of approximately $3 \mathrm{~m}$ of dark gray, very-fine-grained, siliceous, bioturbated sandstone. The Shublik Formation is interpreted to be deposited in a low-relief ramp-style shelf setting, influenced by marine upwelling (Kelly and others, 2007; Parrish and others, 2001). Although formation picks in well data from the northern part of the map area indicate a thickness of 40-45 $\mathrm{m}$ (Nelson and others, 1999), field relations along the upper Kavik River suggest the Shublik may be more than twice that thick, consistent with outcrop measurements elsewhere by Detterman and others (1975). Unit is gas-bearing in the region at the undeveloped Kavik and Kemik fields (Verma and others, 2005; Bird, 1999).

SADLEROCHIT GROUP (Permian to Middle Triassic) — Composed principally of siliciclastic rocks, including the dominantly marine Permian Echooka Formation and nonmarine to marine Ivishak Formation (Detterman and others, 1975).

IVISHAK FORMATION (Lower to Middle Triassic) —-In the northeastern Brooks Range, the Ivishak Formation is subdivided into three lithostratigraphic units, in ascending order: the Kavik Member, Ledge Sandstone Member, and the Fire Creek Siltstone Member (Detterman and others, 1975). In the map area, the Ledge Sandstone and Kavik members are mapped separately wherever possible, although locally an undifferentiated 
unit is applied; the Fire Creek Siltstone Member proved unresolvable as a map unit and is here included in the Ledge Sandstone Member.

Kiu IVISHAK FORMATION, UNDIFFERENTIATED (Lower to Middle Triassic)-Undifferentiated Ivishak Formation, applied where constituent members are poorly exposed and cannot be reliably distinguished.

Kil IVISHAK FORMATION, LEDGE SANDSTONE MEMBER (Lower to Middle Triassic)—Reddish-brown-weathering, thin- to medium-bedded, moderately resistant, light to medium gray, well cemented, fine- to very-fine-grained quartzose sandstone; beds are commonly massive, although ripple, planar, and convolute lamination is locally observed. Dark, reddish brown siltstone and argillaceous siltstone varies from weakly to well laminated and includes starved ripple facies; bioturbated siltstone increases upsection to form a fine-grained interval that is thinner than the underlying sandstone-dominated interval. This poorly exposed siltstone is likely correlative with the Fire Creek Siltstone Member (Detterman and others, 1975). Unit is gradational from underlying Kavik Member. Interpreted to record the progradation and retrogradation of the distal part of a deltaic complex (McMillen and Colvin, 1987; Crowder, 1990; LePain and Wartes, in press). A thickness of $250 \mathrm{~m}$ was estimated along the Kavik River. Unit is gas-bearing in the undeveloped Kavik field in the north-central part of the map (Verma and others, 2005).

Kik IVISHAK FORMATION, KAVIK SHALE MEMBER (Lower Triassic)—Reddish-brown-weathering, dark gray, laminated siltstone and thin-bedded silty shale. Rarely exposed and typically forms a recessive swale between the competent Echooka Formation and Ledge Sandstone Member of the Ivishak Formation. Depositional environment is inferred to be shelfal to prodelta, recording the early distal phases of Triassic deltaic sedimentation (Crowder, 1990). The type section is designated for intermittent exposures along the Kavik River, in the map area, where Detterman and others (1975) calculated a thickness of $85 \mathrm{~m}$; unit appears to be thicker elsewhere in the region.

Pe ECHOOKA FORMATION (Permian)—Hard, dense, silicified, very-fine-grained sandstone and siltstone; commonly medium-, and rarely thick-bedded; finer-grained facies almost cherty in places. Commonly weathers into blocky rubble; typically exhibits a mottled texture and wavy lamination due to thorough bioturbation. Zoophycos trace fossils are well preserved locally and diagnostic; Diplocraterion traces are also present. Local thin beds and lenses of limestone and silicified limestone are more common in the lower part of the section and host brachiopods, solitary corals, bryozoans, and sponge spicules. Forms prominent dark-brown- to rust-red-weathering flat irons and cuestas; color likely results from oxidation of disseminated pyrite. Unit is commonly covered by conspicuous orange lichen. Interpreted to be deposited in a low-energy shelfal setting, below storm wave base (LePain and Wartes, in press). Unit thickness is regionally variable, and outcrops in the Sadlerochit Mountains, east of the map area, indicate abrupt northward thinning (Crowder, 1990; Detterman and others, 1975); estimated to be approximately $100 \mathrm{~m}$ thick along the Kavik River, although Keller and others (1961) reported locally thicker sections in the area. Detterman and others (1975) subdivided the Echooka Formation into two parts, the Joe Creek and Ikiakpaurak members; exposure quality in the map area does not permit their differentiation as map units.

LISBURNE GROUP (Mississippian to Lower Pennsylvanian) - A resistant, commonly cliff-forming, limestone-dominated unit recording the development of a vast carbonate platform across much of Arctic Alaska. At least $500 \mathrm{~m}$ thick; exposures are limited to alpine topography in the southernmost part of the map area. In the northeastern Brooks Range, this unit is commonly subdivided into the Alapah Limestone (lower unit) and the Wahoo Limestone (upper unit; Brosgé and others, 1962; Watts and others, 1995). In this area, stratigraphic criteria are not sufficiently unique to map these units as biostratigraphically defined. Instead, informal lower, middle, and upper units were chosen. 
PMImu LISBURNE GROUP, MIDDLE AND UPPER PARTS-Mapped as undifferentiated, particularly in the southwestern corner of the map area.

PMIU LISBURNE GROUP, UPPER PART - Light-gray-weathering limestone and subordinate buffweathering dolostone. Resistant and commonly forms cliffs. Depositional cycles ranging from 10 to $20 \mathrm{~m}$ thick form distinctive stepped topography where well exposed. Thin- to thick-bedded bioclastic grainstone and wackestone with abundant crinoidal and subordinate coral debris; lime mud interbeds. Local light-colored nodular chert. Corresponds approximately with Wahoo Limestone.

MIm LISBURNE GROUP, MIDDLE PART-Medium-gray-weathering limestone with abundant crinoidal debris. Less resistant than upper part and commonly rubbly, but locally forms cliffs. Thin- to medium-bedded with more abundant lime-mud interbeds than in upper part. Thinner cycles than in upper part that consist of alternating rubbly and resistant intervals. Corresponds approximately with upper Alapah Limestone.

MII LISBURNE GROUP, LOWER PART-Dark-gray-weathering limestone with common black nodular chert layers and lenses. Typically recessive and rubbly, but local outcrops display alternating thin, resistant, and recessive beds. Common solitary and colonial corals in dark lime-mud matrix. Corresponds approximately with lower Alapah Limestone and may include rocks assigned to the Wachsmuth Limestone by Brosgé and others (1962).

ENDICOTT GROUP (Lower to Middle Mississippian) - The Endicott Group is the basal part of the Ellesmerian sequence and is separated from underlying pre-middle Devonian rocks by a major angular unconformity. This siliciclastic-dominated assemblage is composed in ascending order of the Kekiktuk Conglomerate and Kayak Shale; exposures are limited to the core of the Echooka Anticlinorium (Meigs and Imm, 1995) in the southwestern corner of the map area.

Mky KAYAK SHALE (Middle Mississippian) —Dark gray to black siltstone and fissile sooty shale; upper part includes locally fossiliferous limestone beds that are gradational with the overlying Lisburne Group. Restricted to the southwestern corner of the map, largely west of Juniper Creek, where limited exposures crop out in recessive swales beneath the resistant, cliff-forming Lisburne Group. Interpreted as a transgressive marginal marine succession (LePain, 1998). Sections measured south and east of the map area yield thickness estimates ranging from 90 to more than $300 \mathrm{~m}$ (LePain and Crowder, 1990); although poorly constrained in the map area, thickness is probably less than $250 \mathrm{~m}$.

Mkt KEKIKTUK CONGLOMERATE (Lower to Middle Mississippian) - Gray-brown-weathering, resistant, massive, fine- to very-fine-grained quartzite and indurated siltstone. Confined to southwestern part of map area, in core of Echooka Anticlinorium. Regional interpretations suggest deposition in fluvial systems, although marginal marine influence in the upper part is possible where it transitions upward into the Kayak Shale (LePain and others, 1994). Thickness is regionally influenced by paleotopographic relief on the basal unconformity (LePain and others, 1994); thickness in field area is poorly constrained, but probably not more than a few tens of meters.

\section{PRE-MISSISSIPPIAN ROCKS}

Includes all rocks preserved beneath the major pre-middle Devonian unconformity. Often called the Franklinian sequence, a term generally no longer in widespread use (Moore and others, 1994). East of the map area, a number of units are recognized in the Sadlerochit and Shublik Mountains (Robinson and others, 1989), including Neruokpuk formation, Katakturuk Dolomite, Nanook Limestone, and Mount Copleston Limestone (Blodgett and others, 1992).

pM PRE-MISSISSIPPIAN ROCKS, UNDIFFERENTIATED (Proterozoic[?])—Dark gray phyllite, argillite, and light gray, thin quartzite. Only present in core of the Echooka Anticlinorium in the southwestern corner of map area. Possibly correlative to the Proterozoic(?) Neruokpuk Formation as narrowly defined by Reiser and others (1978), which is exposed along structural strike to the east of the map area. 


\section{ACKNOWLEDGMENTS}

Geologic mapping was supported in part by the National Cooperative Geologic Mapping Program's STATEMAP program under award number 06HQAG0024, administered by the U.S. Geological Survey. Additional funding was provided through a State of Alaska Capital Improvement Project grant. Additional support for field studies provided by a consortium of sponsors including Conoco Phillips, Anadarko, ENI, Petro-Canada, BG Alaska, FEX, Pioneer Natural Resources, and Shell.

C.G. 'Gil' Mull freely shared his knowledge of the area, including unpublished mapping; his guidance and support were greatly appreciated. This work also benefited from numerous discussions with colleagues including D. Houseknecht, R. Swenson, K. Bird, D. van der Kolk, M. Whalen, P. McCarthy, and D. Shellenbaum. A special thanks to Joe Henderson, generous host of the Kavik camp. We also wish to thank the Arctic National Wildlife Refuge for permission to conduct mapping in the refuge.

Both the map and associated text were improved significantly after thorough reviews by David Houseknecht and Thomas Homza.

\section{REFERENCES CITED}

Bader, J.W., and Bird, K.J., 1986, Geologic map of the Demarcation Point, Mt. Michelson, Flaxman Island, and Barter Island quadrangles, Alaska: U.S. Geological Survey Miscellaneous Investigations Map I-1791, 1 sheet, scale $1: 250,000$.

Bergman, S.C., Decker, J., and Talbot, J., 1995, Upper Cretaceous tephra deposits, Canning River area, north Alaska: Geological Society of America, Cordilleran Section Meeting, Abstracts with Program, v. 27, no. 5, p. 5.

Bird, K.J., 1987, The framework geology of the North Slope of Alaska as related to oil-source rock correlations, in Tailleur, I.L., and Weimer, Paul, eds., Alaskan North Slope geology: Bakersfield, California, Society of Economic Paleontologists and Mineralogists, Pacific Section, and Alaska Geological Society, no. 50, vol. 1, p. 121-143.

-1999, Geographic and geologic setting, The oil and gas resource potential of the 1002 Area, Arctic National Wildlife Refuge, Alaska, in ANWR Assessment Team, eds., The oil and gas resource potential of the 1002 Area, Arctic National Wildlife Refuge, Alaska: U.S. Geological Survey Open-File Report 98-34, chapter GG, p. GG-1-GG-51, http://pubs.usgs.gov/of/1998/ofr-98-0034/.

Bird, K.J., and Molenaar, C.M., 1992, The North Slope foreland basin, Alaska, in Macqueen, R.W., and Leckie, D.A., eds., Foreland basins and foldbelts: American Association of Petroleum Geologists, Memoir 55, p. 363-393.

Blodgett, R.B., Clough, J.G., Harris, A.G., and Robinson, M.S., 1992, The Mount Copleston Limestone, a new Lower Devonian formation in the Shublik Mountains, northeastern Brooks Range, Alaska, in Bradley, D.C., and Ford, A.B., eds., Geologic studies in Alaska by the U.S. Geological Survey, 1990: U.S. Geological Survey Bulletin 1999, p. 3-7.

Bouma, A.H., 1962, Sedimentology of some flysch deposits - A graphic approach to facies interpretation: Amsterdam, Elsevier, 168 p.

Brosgé, W.P., Dutro, J.T., Jr., Mangus, M.D., and Reiser, H.N., 1962, Paleozoic sequence in eastern Brooks Range, Alaska: American Association of Petroleum Geologists Bulletin, v. 46, no. 12, p. 2,174-2,198.

Buckingham, M.L., 1987, Fluvial-deltaic sedimentation patterns of the Upper Cretaceous to Lower Tertiary Jago River Formation, Arctic National Wildlife Refuge (ANWR), northeastern Alaska, in Tailleur, I.L, and Weimer, Paul, eds., Alaska North Slope geology: Anchorage, Alaska and Bakersfield, California, Alaska Geological Society and Pacific Section, Society of Economic Paleontologists and Mineralogists, vol. 50, p. 529-540.

Burruss, R.C., 1999, Evidence for petroleum occurrence and timing of migration: Petroleum fluid inclusions, dead oil, stains, and seeps, in ANWR Assessment Team, eds., The oil and gas resource potential of the 1002 Area, Arctic National Wildlife Refuge, Alaska: U.S. Geological Survey Open-File Report 98-34, chapter FI, p. FI-1-FI-29, http://pubs.usgs.gov/of/1998/ofr-98-0034/.

Camber, W., and Mull, C.G., 1986, Preliminary bedrock geologic map of part of the Demarcation Point A-3 and A-4 quadrangles, Bathtub Ridge, northeastern Alaska: Alaska Division of Geological \& Geophysical Surveys Public-Data File 86-86C, 10 p., 3 sheets, scale $1 \mathrm{~cm}=2 \mathrm{~m}$.

Carmen, G.J., and Hardwick P., 1983, Geology and regional setting of Kuparuk Oil Field, Alaska: American Association of Petroleum Geology Bulletin, v. 67, no. 6, p.1,014-1,031.

Carson, E.C., 2009, Surficial-geologic map of the Kavik River area, west-central Mount Michelson Quadrangle, northeastern Brooks Range, Alaska: Alaska Division of Geological \& Geophysical Surveys Report of Investigation 2009-3, 1 sheet, scale 1:63,360. 
Catuneanu, O., Abreu, V., Bhattacharya, J.P., Blum, M.D., Dalrymple, R.W., Eriksson, P.G., Fielding, C.R., Fisher, W.L., Galloway, W.E., Gibling, M.R., Giles, K.A., Holbrook, J.M., Jordan, R., Kendall, C.G.St.C., Macurda, B., Martinsen, O.J., Miall, A.D., Neal, J.E., Nummedal, D., Pomar, L., Posamentier, H.W., Pratt, B.R., Sarg, J.F., Shanley, K.W., Steel, R.J., Strasser, A., Tucker, M.E., and Winker, C., 2009, Towards the standardization of sequence stratigraphy: Earth-Science Reviews, v. 92, no. 1-2, p. 1-33.

Crowder, R.K., 1990, Permian and Triassic sedimentation in the northeastern Brooks Range, Alaska-Deposition of the Sadlerochit Group: American Association of Petroleum Geologists Bulletin, v. 74, no. 9, p. 1,351-1,370.

Decker, P.L., LePain, D.L., Wartes, M.A., Gillis, R.J., Mongrain, J.R., Kirkham, R.A., and Shellenbaum, D.P., in press, Sedimentology, Stratigraphy and Subsurface Expression of Upper Cretaceous Strata in the Sagavanirktok River Area, East-Central North Slope, Alaska, in Wartes, M.A., and Decker, P.L., eds., Preliminary results of recent geologic field investigations in the Brooks Range foothills and North Slope, Alaska, vol 2: Alaska Division of Geological \& Geophysical Surveys Preliminary Interpretive Report.

Decker, P.L., Wartes, M.A., Wallace, W.K., Houseknecht, D.W., Schenk, C.J., Gillis, R.J., and Mongrain, Jacob, 2008, Stratigraphic and structural investigations in the Ivishak River and Gilead Creek areas: Progress during 2007, in Wartes, M.A., and Decker, P.L., eds., Preliminary results of recent geologic field investigations in the Brooks Range foothills and North Slope, Alaska, vol. 1: Alaska Division of Geological \& Geophysical Surveys Preliminary Interpretive Report 2008-1F, p. 55-83, 1 sheet.

Detterman, R.L., Reiser, H.N., Brosgé, W.P., and Dutro, J.T., Jr., 1975, Post-Carboniferous stratigraphy, northeastern Alaska: U.S. Geological Survey Professional Paper 886, 46 p.

Garrity, C.P., Houseknecht, D.W., Bird, K.J., Potter, C.J., Moore, T.E., Nelson, P.H., and Schenk, C.J., 2005, U.S. Geological Survey 2005 oil and gas resource assessment of the central North Slope, Alaska: U.S. Geological Survey Open-File Report 2005-1182, http://pubs.usgs.gov/of/2005/1182/, 29 p.

Houseknecht, D.W., and Schenk, C.J., 1999, Seismic facies analysis and hydrocarbon potential of Brookian strata, Chapter BS (Brookian Sequences), in ANWR Assessment Team, eds., The oil and gas resource potential of the 1002 Area, Arctic National Wildlife Refuge, Alaska: U.S. Geological Survey Open-File Report 98-34, p. BS-1-BS-60, http://pubs.usgs.gov/of/1998/ofr-98-0034/.

Hsu, K.J., 1968, Principles of mélanges and their bearing on the Franciscan-Knoxville paradox: Geological Society of America Bulletin, v. 79, p. 1,063-1,074.

Hubbard, R.J., Edrich, S.P., and Rattey, R.P., 1987, Geologic evolution and hydrocarbon habitat of the Arctic Alaska microplate, in Tailleur, I.L., and Weimer, Paul, eds., Alaskan North Slope geology: Bakersfield, California, Society of Economic Paleontologists and Mineralogists, Pacific Section, and Alaska Geological Society, Book 50, v. 2, p. 797-830.

Keller, A.S., Morris, R.E., and Detterman, R.L., 1961, Geology of the Shaviovik and Sagavanirktok rivers region, Alaska: U.S. Geological Survey Professional Paper 303-D, p. 169-219.

Kelly, L.N., Whalen, M.T., McRoberts, C.A., Hopkin, E., and Tomsich, C.S., 2007, Sequence stratigraphy and geochemistry of the upper Lower through Upper Triassic of northern Alaska-Implications for paleoredox history, source rock accumulation, and paleoceanography: Alaska Division of Geological \& Geophysical Surveys Report of Investigation 2007-1, 50 p.

Knock, D.G., 1986, Thirty-seven measured sections of Lower Cretaceous Kemik Sandstone, northeastern Alaska: Alaska Division of Geological \& Geophysical Surveys Public-Data File 86-86B, 25 p., 7 sheets, scale $1 \mathrm{~cm}=2 \mathrm{~m}$.

Leffingwell, E.d.K., 1919, The Canning River region, northern Alaska: U.S. Geological Survey Professional Paper 109, 251 p., 6 sheets, scale 1:125,000.

LePain, D.L., 1998, Paleotopographic control on deposition of the Lower Kayak Shale, northern Franklin Mountains, Brooks Range, Alaska, in Clough, J.G., and Larson, Frank, eds., Short Notes on Alaska geology 1997: Alaska Division of Geological \& Geophysical Surveys Professional Report 118, p. 71-85.

LePain, D.L., and Crowder, R.K., 1990, Detailed measured sections from the Endicott Group (Mississippian) in the Shublik Mountains, Fourth Range, and Franklin Mountains, northeastern Brooks Range, Alaska: Alaska Division of Geological \& Geophysical Surveys Public-Data File 90-2C, 73 p.

LePain, D.L., Crowder, R.K., and Wallace, W.K., 1994, Early Carboniferous transgression on a passive continental margin-Deposition of the Kekiktuk Conglomerate, northeastern Brooks Range, Alaska: AAPG Bulletin, May 1994, v. 78, no. 5, p. 679-699.

LePain, D.L, and Wartes, M.A., in press, Measured sections of the Permian Echooka and Triassic Ivishak Formations, Shaviovik River, eastern Sagavanirktok Quadrangle, in Wartes, M.A., and Decker, P.L., eds., Preliminary 
results of recent geologic field investigations in the Brooks Range foothills and North Slope, Alaska, vol. 2: Alaska Division of Geological \& Geophysical Surveys Preliminary Interpretive Report.

Lerand, M., 1973, Beaufort Sea, in McCrossam, R.G., ed., The future petroleum provinces of Canada-Their geology and potential: Canadian Society of Petroleum Geology Memoir 1, p. 315-386.

Macquaker, J.H.S., and Keller, M.A., 2005, Mudstone sedimentation at high latitudes-Ice as a transport medium for mud and supplier of nutrients: Journal of Sedimentary Geology, v. 75, no. 4, p. 696-709.

Macquaker, J.H.S., Keller, M.A., and Taylor, K.G., 1999, Sequence stratigraphic analysis of the lower part of the Pebble Shale Unit, Canning River, northeastern Alaska, in ANWR Assessment Team, eds., The oil and gas resource potential of the 1002 Area, Arctic National Wildlife Refuge, Alaska: U.S. Geological Survey OpenFile Report 98-34, p. SS-1-SS-28, http://pubs.usgs.gov/of/1998/ofr-98-0034/.

McMillen, K.J., and Colvin, M.D., 1987, Facies correlation and basin analysis of the Ivishak Formation, Arctic National Wildlife Refuge, Alaska, in Tailleur, I.L., and Weimer, Paul, eds., Alaskan North Slope Geology: SEPM Pacific Section Field Trip Guidebook, v. 50, p. 381-390.

Meigs, A.J., and Imm, T.A., 1995, Geometry and deformation of a duplex and its roof layer-Observations from the Echooka Anticlinorium, northeastern Brooks Range, Alaska, in Combellick, R.A., and Tannian, F., eds., Short Notes on Alaska Geology 1995: Alaska Division of Geological \& Geophysical Surveys Professional Report 117, p. 19-31.

Molenaar, C.M., 1983, Depositional relations of Cretaceous and lower Tertiary rocks, northeastern Alaska: American Association of Petroleum Geologists Bulletin, v. 67, no. 7, p. 1,066-1,080.

Molenaar, C.M., Bird, K.J., and Collett, T.S., 1986, Regional correlation sections across the North Slope of Alaska: U.S. Geological Survey Miscellaneous Field Studies 1907, 1 sheet.

Molenaar, C.M., Bird, K.J., and Kirk, A.R., 1987, Cretaceous and Tertiary stratigraphy of northeastern Alaska, in Tailleur, I.L., and Weimer, Paul, eds., Alaskan North Slope Geology, Volume 2: Pacific Section, Society of Economic Paleontologists and Mineralogists and Alaska Geological Society, v. 50, p. 513-528.

Moore, T.E., Wallace, W.K., Bird, K.J., Karl, S.M., Mull, C.G., and Dillon, J.T., 1994, Chapter 3: Geology of northern Alaska, in Plafker, George, and Berg, H.C., eds., The Geology of Alaska: The Geology of North America, Geological Society of America, Boulder, Colorado, v. G1, p. 49-140.

Mull, C.G., 1987, The Kemik Sandstone, Arctic National Wildlife Refuge, northeastern Alaska, in Tailleur, I.L., and Weimer, Paul, eds., North Slope Geology: Society of Economic Paleontologists and Mineralogists, Pacific Section, and Alaska Geologic Society, p. 404-431.

Mull, C.G., and Decker, J.E., 1993, Organic-rich shale and bentonite in the Arctic Creek unit, Arctic National Wildlife Refuge-Implications for stratigraphic and structural interpretations, in Solie, D.N., and Tannian, F., eds., Short Notes on Alaskan Geology 1993: Alaska Division of Geological \& Geophysical Surveys Professional Report 113, p. 41-49.

Mull, C.G., Houseknecht, D.W., and Bird, K.J., 2003, Revised Cretaceous and Tertiary stratigraphic nomenclature in the Colville basin, northern Alaska: U.S. Geological Survey Professional Paper 1673, 51 p.

Nelson, P.H., J.E. Kibler, and C.P. Giberson, 1999, Well data and well plots, Chapter WL, in ANWR Assessment Team, ed., The oil and gas resource potential of the Arctic National Wildlife Refuge 1002 Area, Alaska: U.S. Geological Survey Open-File Report 98-34, p. WL1-WL84, http://pubs.usgs.gov/of/1998/ofr-98-0034.

Parrish, J.T., Droser, M.L., and Bottjer, D.J., 2001, A Triassic upwelling zone-the Shublik Formation, Arctic Alaska, USA: Journal of Sedimentary Research, v. 71, no. 2, p. 272-285.

Reifenstuhl, R.R., 1991, Gilead sandstone, northeastern Brooks Range, Alaska-An Albian to Cenomanian marine clastic succession, in Reger, R.D., ed., Short Notes on Alaskan Geology 1991: Alaska Division of Geological \& Geophysical Surveys Professional Report 111, p. 69-76.

Reifenstuhl, R.R., 1995, Lithofacies, petrology, and petrophysics of the Kemik Sandstone (Lower Cretaceous), eastern Arctic Slope, Alaska, in Combellick, R.A., and Tannian, F., eds., Short Notes on Alaska Geology, 1995: Alaska Division of Geological \& Geophysical Surveys Professional Report 117, p. 53-67.

Reifenstuhl, R.R., Mull, C.G., Harris, E.E., LePain, D.L., Pinney, D.S., and Wallace, W.K., 2000, Geologic map of the Sagavanirktok B-1 Quadrangle, eastern North Slope, Alaska: Alaska Division of Geological \& Geophysical Surveys Report of Investigation 2000-1A, 15 p., 1 sheet, scale 1:63,360.

Reiser, H.N., Norris, D.K., Dutro, J.T., Jr., and Brosgé, W.P., 1978, Restriction and renaming of Neruokpuk Formation, northeastern Alaska, in Sohl, N.F., and Wright, W.B., eds., Changes in stratigraphic nomenclature by the U.S. Geological Survey, 1977: U.S. Geological Survey Bulletin 1457-A, p. A106-A107. 
Reiser, H.N., Brosgé, W.P., Dutro, J.T., Jr., and Detterman, R.L., 1971, Preliminary geologic map, Mt. Michelson Quadrangle, Alaska: U.S. Geological Survey Open-File Report 71-237, 2 sheets, scale 1:200,000.

Robinson, M.S., Decker, John, Clough, J.G., Reifenstuhl, R.R., Bakke, Arne, Dillon, J.T., Combellick, R.A., and Rawlinson, S.E., 1989, Geology of the Sadlerochit and Shublik Mountains, Arctic National Wildlife Refuge, northeastern Alaska: Alaska Division of Geological \& Geophysical Surveys Professional Report 100, 1 sheet, scale $1: 63,360$.

Schenk, C.J., and Houseknecht, D.W., 2008, Geologic model for oil and gas assessment of the Kemik-Thomson play, central North Slope, Alaska: U.S. Geological Survey Scientific Investigations Report 2008-5146, 28 p.

Tailleur, I.L., Pessel, G.H., and Engwicht, S.E., 1978, Folio, eastern North Slope petroleum province: U.S. Geological Survey Miscellaneous Field Studies Map MF 928A, 8 p.

van der Kolk, D.A., 2010, Geochemistry, sedimentology, and stratigraphy of the Lower Cretaceous Pebble Shale unit, northeastern Alaska: Fairbanks, University of Alaska Fairbanks Master's Thesis, 116 p.

Verma, M.K., Bird, K.J., Nelson, P.H., and Burruss, R.C., 2005, Evaluation of the stranded Kavik Gas Field, North Slope of Alaska [poster]: U.S. Geological Survey Open-File Report 2005-1389, http://pubs.usgs.gov/ of/2005/1389/.

Wallace, W.K., in review, Interpretations of seismic reflection data and structural cross sections for the Kavik River map area: Alaska Division of Geological \& Geophysical Surveys Report of Investigations, 3 sheets.

Wartes, M.A., Decker, P.L., Houseknecht, D.W., Gillis, R.J., and LePain, D.L., 2011, Foreland basin response to Paleocene rejuvenation in the Brooks Range, northern Alaska: AAPG 3-P (Polar Petroleum Potential) Conference and Exhibition, Halifax, Nova Scotia, http://www.3parctic.com/2011/conference/technical-sessions.htm.

Watts, K.F., Harris, A.G., Carlson, R.C., Eckstein, M.K., Gruzlovic, P.D., Imm, T.A., Krumhardt, A.P., Lasota, D.K., Morgan, S.K., Enos, P., Goldstein, R.H., Dumoulin, J.A., and Mamet, B.L., 1995, Analysis of reservoir heterogeneities due to shallowing-upward cycles in carbonate rocks of the Pennsylvanian Wahoo Limestone of northeastern Alaska: U.S. Department of Energy, Final Report for 1989-1992, Bartlesville Project Office. 